\title{
PENGARUH STRATEGI ANTICIPATION GUEDE TERHADAP \\ KEMAMPUAN MENELAAH TEKS ULASAN PADA SISWA \\ KELAS VIII SMP NEGERI 1 AEK KUASAN \\ TAHUN PEMBELAJARAN 2018/2019
}

\author{
Oleh \\ Indah Atika Suri (indahatikasuri71@gmail.com) \\ Khairil Ansari (Khairil.ansary@gmail.com) \\ Universitas Negeri Medan
}

\begin{abstract}
ABSTRAK
Penelitian ini mengkaji tentang keterampilan menelaah teks ulasan pada puisi dengan Strategi Anticipation Guede.Penelitian ini bertujuan untuk mengetahui pengaruh Strategi Anticipation Guede terhadap kemampuan menelaah teks ulasan puisi pada siswa kelas VIII SMP Negeri 1 Aek Kuasan tahun pembelajaran 2018/2019.Populasi dalam penelitian ini adalah seluruh siswa kelas VIII yang terdiri atas 7 kelas yang berjumlah 252 siswa.Sampel penelitian ini adalah kelas berjumlah 72 siswa.Penelitian ini menggunakan metode eksperimen.Desain penelitian yang digunakan one group pretest posttest design.Berdasarkan pengolahan data diperoleh hasil pretest dengan rata-rata $=41$ dan standar deviasi $=12$. Sedangkan hasil posttest dengan rata-rata $=69,5$ dan standar deviasi $=8,0$. Data pretest diperoleh $\mathrm{L}_{\text {hitung }}<\mathrm{L}_{\text {tabel }}(0,<09220,185)$ dan data posttest diperoleh $\mathrm{L}_{\text {hitung }}<\mathrm{L}_{\text {tabel }}(0,1192<0,185)$. Sedangkan dari uji homogenitas diperoleh bahwa sampel penelitian ini berasal dari kelompok yang homogen yaitu $F_{\text {hitung }}<F_{\text {tabel }}$ $(1,28<1,96) .5 \%$ adalah $\mathrm{df}=\mathrm{n}-1, \mathrm{df}=72-1=71$ diperoleh taraf signifikan $5 \%$ adalah 2,06. Oleh karena to yang diperoleh dari $t_{\text {tabel }}$ yaitu 5,97 >c 2,06, maka hipotesis alternatif (Ha) diterima. Hal ini membuktikan bahwa strategi Anticipation Guedeberpengaruhterhadap kemampuan menelaah teks ulasan puisi pada siswa kelas VIII SMP Negeri 1 Aek Kuasan Tahun Pembelajaran 2018/2019.
\end{abstract}

Kata kunci : teks ulasan, puisi, Strategi Anticipation Guede

\section{PENDAHULUAN}

Teks ulasan adalah pertimbangan, kajian, bedah, telaah, tafsiran, atau referensi, dimana merupakan penelitian terhadap kualitas suatu karya dari kelebihan dan kekuranganya (Latsia, 2016). Dalam pembelajaran teks ulasan ini banyak para siswa mengalami kesulitan dalam menelaah teks ulasan, sehingga digunakan lah strategi Anticipation Guede dalam 
penerapan nya, karena dengan strategi Anticipation Guede merupakan kegiatan membaca yang membantu untuk mengaktifkan pengetahuan awal siswa dan membimbing siswa dalam memahami teks, panduan Antisipasi adalah strategi yang baik untuk mengajarkan fiksi, non-fiksi, dan segala macam teks. Selain itu, Antisipasi Panduan memiliki banyak manfaat bagi siswa. Pertama-tama, itu memperkuat keterampilan pemahaman Penggunaan kuriku lum 2013 di SMP Negeri 1 Aek Kuasan menjadikan teks ulasan menjadi materi pokok dalam mata pelajaran bahasa Indonesia dikelas VIII. Peserta didik mulai mempelajari teks ulasan dengan panduan buku paket/buku pegangan belajar siswa yang diberikan dari sekolah.

Penelitian terdahulu yang
dilakukan oleh Antoni (2017)
dengan judul "Pengaruh strategi
panduan guede dan minat belajar
siswa pada komprehensi bacaan pada
siswa dikelas XII SMKN 1
Pariaman" dengan menggunakan
strategi Anticipation Guede peneliti

mendapatkan hasil yang signifikan pada pemahaman membaca siswa dari pada diskusi kelompok kecil dan tidak ada interaksi antara strategi mengajar dan minat baca pada pemahaman membaca siswa. Hal ini dibuktikan dengan hasil uji $\mathrm{t}$ yang menunjukan bahwa toserved lebih besar dari ttabel.

$$
\text { Sudjana (2016: }
$$

mengemukakan bahwa strategi pembelajaran mencakup penggunaan pendekatan, metode, teknik, bentuk media, sumber belajar, pengelompokkan peserta didik untuk mewujudkan interaksi edukasi antara pendidik dengan peserta didik, antar peserta didik, dan antara peserta didik dengan lingkungannya. Tujuan strategi pembelajaran adalah terwujudnya efisiensi dan efektivitas kegiatan belajar yang dilakukan peserta didik. Metode mengajar merupakan cara atau teknik penyampaian materi pembelajaran yang harus dikuasai oleh guru. Metode mengajar ditetapkan berdasarkan tujuan, materi pembelajaran, serta karakterisik siswa. Oleh sebab itu sebelum menentukan strategiperlu 
dirumuskan tujuan yang dapat diukur keberhasilannya, sebab tujuan adalah rohnya dalam mengimplementasi suatu strategi. Strategi panduan antisipasi (anticipation guide) merupakan strategi untuk meningkatkan pemahaman siswa dengan meminta siswa untuk bereaksi terhadap pernyataan yang memusatkan perhatian mereka pada topik yang harus dipelajari (Tierney, 1990:45-46). Panduan antisipasi menyajikan format pembelajaran yang digunakan oleh guru untuk mengidentifikasi pengetahuan awal siswa tentang topik yang akan dipelajari dan untuk memotivasi mereka untuk mengejar informasi apa yang terdapat dalam bacaan tersebut.

Tierney (1990) merancang strategi panduan antisipasi untuk mengaktifkan pengetahuan siswa tentang sebuah topik sebelum siswa mulai membaca dan memandu siswa dalam proses membaca selanjutnya. Strategi panduan antisipasi bertujuan untuk memperluas pemahaman membaca siswa dengan cara menuntun mereka untuk menanggapi pernyataan-pernyataan tentang sebuah topik sebelum siswa mulai membaca atau untuk mengikutsertakan siswa dalam kegiatan- kegiatan lain sehingga siswa dapat menggali informasi. Strategi ini memanfaatkan prediksi atau dugaan sementara dengan mengaktifkan pengetahuan yang dimiliki siswa sebelumnya dan juga menggunakan diskusi sebagai sebuah motivasi agar siswa dapat terlibat dalam materi yang akan dibaca.

Oleh karena itu dari penjelasan para ahli diatas bahwa jelas strategi Anticipation Guede ini bagus untuk diterapkan terutama dalam pembelajaran terutama pembelajaran berbasis teks, dengan membaca semua siswa tau materi yang telah di baca kemudian dengan bantuan dan penggunaan strategi anticipation guede ini siswa dapat lebih tanggap dan kritis dalam menelaah teks yang telah di baca dan disediakan. Sehingga dapat lebih efektif dan memudahkan guru untuk menguasai pembelajaran yang sedang berlangsung.

Kelebihan strategi ini menurut Tierney (1990) yaitu sebagai berikut: 
1) membantu siswa dalam berpikir kritis, Strategi ini dilaksanakan dengan mengaktifkan pengetahuan awal siswa terhadap serangkaian pernyataan tentang suatu topik. Serangkaian pernyataan yang diberikan menjadi panduan siswa dalam kegiatan membaca selanjutnya. Respon kritis lain juga diberikan siswa melalui kegiatan diskusi setelah membaca teks.

2) Menciptakan Kegiatan diskusi yang dapat menumbuhkan rasa percaya diri siswa dan pemahaman siswa terhadap bacaan. Anticipation Guides berpotensi memotivasi minat siswa dan memperkuat keterampilan pemahaman Menurut Kozen (2006:195).

Oleh karena itu Kelebihan strategi panduan antisipasi yaitu strategi ini mengaktifkan pengetahuan siswa, mengembangkan kegiatan membaca aktif dan terarah serta memperkuat konsep yang diambil dari teks.Siswa dapat berlatih berdiskusi dan mengemukakan pendapat. Strategi panduan antisipasi juga memiliki kekurangan menurut Tierney (1990) yaitu sebagai berikut:

1) Strategi Anticipation tidak sepenuhnya mendorong siswa untuk menjadi pembaca aktif dan tidak mendapatkan minat baca siswa. Karena kemampuan siswa dari setiap anak berbeda-beda ada siswa berprestasi tinggi cenderung mendominasi kegiatan diskusi, sedangkan siswa berprestasi rendah hanya diam selama kegiatan.

2) Faktor potensial lain yang menyebabkan masalah siswa dalam memahami teks adalah minat baca siswa. Menurut Khairuddin (2013: 162) "minat baca adalah salah satu prediktor terbaik pertumbuhan anak dalam membaca". Teori ini menunjukkan bahwa minat baca secara tidak langsung mempengaruhi pemahaman membaca siswa. 
Brophy (2010: 184) menyatakan bahwa minat menyiratkan perhatian terfokus pada pelajaran, bagian teks, atau aktivitas pembelajaran yang terjadi karena nilai pelajar atau memiliki tanggapan afektif positif terhadap konten atau prosesnya.Selain itu, Ahira (2014) menjelaskan "minat baca dapat diklasifikasikan sebagai keinginan, emosi yang baik, dan respons".

Readence, Bean, and Baldwin (melalui Tierney, 1990) Penerapan strategi Anticipation Guide dilakukan melalui delapan langkah sebagai berikut:

1. Identifikasi konsep utama Langkah pertama guru membaca teks dengan cermat untuk menentukan konsep utama teks tersebut. Konsep utama digunakan sebagai panduan siswa dalam membaca. Kegiatan ini termasuk dalam tahap perencanaan pembelajaran.

2. Menentukan pengetahuan siswa tentang konsep-konsep Langkah ini dilaksanakan guru dengan menanyakan pada siswa tentang suatu judul yang berkaitan dengan bacaan untuk mengetahui latar belakang pengetahuan siswa.
3. Membuat pernyataanpernyataan

Siswa membuat pernyataan yang berkaitan dengan topik yang telah diberikan guru.Banyak sedikitnya pernyataan tergantung pada tanggapan siswa terhadap topik yang berkaitan dengan bacaan.

4. Memutuskan urutan pernyataan dan model presentasi

Guru menentukan urutan-urutan pernyataan untuk digunakan sebagai panduan dan membuat model presentasi yang digunakan dalam menyajikan panduan. Model dapat berupa papan tulis, OHP, atau lembaran tugas yang dibagikan pada siswa secara individu atau kelompok.

\section{Menyajikan panduan}

Guru menyajikan panduan pada siswa. Guru harus menekankan agar siswa mengungkapkan pendapatnya terhadap pernyataan dengan menyatakan persetujuan disertai dengan alasan yang logis. Pada tahap ini siswa dapat bekerja secara mandiri atau berkelompok.

6. Mendiskusikan setiap pernyataan secara singkat 
Siswa mengutarakan pendapatnya berupa setuju atau tidak setuju terhadap pernyataan dengan mengacungkan jari kemudian banyaknya jumlah setuju dan tidak setuju dihitung oleh guru. Siswa harus memberikan alasan yang logis pada setiap pendapat yang disampaikannya melalui diskusi. Pada tahap ini guru berperan sebagai fasilitator.

7. Meminta siswa untuk membaca teks

Siswa membaca teks untuk mencari tahu dan menentukan yang penulis pikirkan terhadap pernyataanpernyataan yang ada di dalam teks.Saat siswa membaca, mereka harus menyimpan dua hal, yaitu pikiran dan pendapatnya juga pendapat teman-teman dan sesuatu yang sedang mereka baca terkait dengan pernyataan-pernyataan yang telah didiskusikan.

8. Mengadakan diskusi lanjutan
Setelah membaca, siswa mendiskusikan kembali topik yang dibicarakan.Siswa harus bereaksi dengan membuat tanggapan berdasarkan informasi yang ada di dalam teks.

\section{METODE}

Metode yang digunakan dalam penelitian ini adalah metode eksperimen dengan desain One group Pretest Posttest Design (Sugiyono 2012:111). Model One Group Pre-test and Post-test Design merupakan eksperimen yang dilaksanakan pada satu kelompok saja tanpa pembanding.

\section{HASIL DAN PEMBAHASAN PENELITIAN}

\section{A. Hasil Penelitian}

Data nilai yang diperoleh dari hasil tes awal menelaah teks ulasan pada siswa kelas VIII SMP Negeri 1 Aek Kuasan adalah sebagai berikut.

\section{Tabel 1}

Identifikasi Kecenderungan Hasil Kemampuan Menelaah Teks Ulasan Siswa sebelum Menggunakan Strategi Anticipation Guede (Pretest)

\begin{tabular}{l|l|l|l}
\hline \multicolumn{1}{c|}{ Interval } & \multicolumn{1}{c|}{ F.Absolut } & \multicolumn{1}{c}{ F.Relatif } & \multicolumn{1}{c}{ Kategori } \\
\hline $85-100$ & 0 & $0 \%$ & Sangat baik \\
\hline $70-84$ & 1 & $1,3 \%$ & Baik \\
\hline
\end{tabular}




\begin{tabular}{l|l|l|l}
\hline $65-74$ & 4 & $5,5 \%$ & Cukup \\
\hline $55-64$ & 27 & $38 \%$ & Kurang \\
\hline $0-54$ & 40 & $56 \%$ & Sangat Kurang \\
\hline Jumlah & 72 & $100 \%$ & \\
\hline \multicolumn{1}{c}{ Berdasarkan tabel di atas, } & kurang baik sebanyak 27 siswa atau \\
maka dapat diketahui bahwa & $38 \%$ Kategori sangat kurang 40 \\
menelaah teks ulasan puisi sebelum & siswa atau 56\% siswa atau \\
menggunakan strategi Anticipation & Identifikasi hasil pre-test yang paling \\
Guede yang termasuk kategori & banyak adalah cukup baik. \\
sangat baik tidak ada atau 0\%, & Data nilai yang diperoleh dari hasil \\
kategori baik sebanyak 1 siswa atau & tes akhir menelaah teks ulasan pada \\
$1,3 \%$, kategori cukup baik sebanyak & siswa kelas VIII SMP Negeri 1 Aek \\
4 siswa atau 5,5\%, dan kategori & Kuasan adalah sebagai berikut.
\end{tabular}

Tabel 2

Identifikasi Kecenderungan Hasil Kemampuan Menelaah Teks Ulasan Siswa sesudah Menggunakan Strategi Anticipation Guede (Post-test)

\begin{tabular}{l|l|l|l}
\hline Interval & F.Absolut & F.Relatif & Kategori \\
\hline $90-98$ & 4 & $6 \%$ & Sangat baik \\
\hline $70-89$ & 36 & $50 \%$ & Baik \\
\hline $60-69$ & 18 & $25 \%$ & Cukup baik \\
\hline$<59$ & 14 & $19 \%$ & Kurang baik \\
\hline Jumlah & 72 & $100 \%$ & \\
\hline
\end{tabular}

Berdasarkan tabel di atas, maka

kategori baik sebanyak 36 siswa atau dapat diketahui bahwa menelaah teks ulasan puisi setelah menggunakan $50 \%$, kategori cukup baik sebanyak strategi Anticipation Guede pada 18 siswa atau 25\%, kategori kurang siswa yang termasuk kategori sangat baik 14 siswa atau 19\%. Identifikasi baik sebanyak 5 siswa atau $6 \%$, hasil tes akhir yang paling banyak adalah kategori Baik. 


\section{B. Pembahasan Penelitian}

\section{Kemampuan Menelaah}

Teks Ulasan Puisi Sebelum

Menggunakan Strategi

\section{Anticipation Guede}

Menurut hasil penelitian tes awal yang diperoleh siswa dalam kemampuan menelaah teks ulasan puisi sebelum menggunakan strategi Anticipation Guede, ditemukan kesulitan dalam memahami dan menelaah teks ulasan puisi yang sudah disediakan. Semua siswa diberikan penjelasan dan keterangan mengenai teks ulasan, kemudian dijelaskan kembali bagaimana menelaah teks ulasan berdasarkan struktur yang sesuai dengan ketentuan. Setelah menjelaskan dan memaparkan semua materi mengenai teks ulasan puisi siswa diberikan tugas untuk menelaah teks ulasan puisi sesuai dengan pusii yang diberikan. Maka berdasarkan soal yang diberikan dapat diperoleh informasi bahwa terdapat $40(56 \%)$ siswa yang skor kemampuan menelaah teks ulasan masuk ke dalam kategori sangat kurang, $27(38 \%)$ siswa yang kemampuan menelaah teks ulasan masuk ke dalam kategori kurang, 4 (5,5\%) siswa yang skor kemampuan menelaah teks ulasan masuk ke dalam kategori cukup, 1 (1,3\%) siswa yang skor kemampuan menelaah teks ulasan masuk kedalam kategori baik, dan $0(0 \%)$ siswa yang skor kemampuan menelaah teks ulasan masuk kedalam kategori sangat baik.

2. Kemampuan Menelaah Teks Ulasan Puisi Setelah Menggunakan Strategi Anticipation Guede

Berdasarkan hasil penelitian yang dilakukan oleh peneliti pada tes akhir yaitu dengan menggunakan strategi Anticipation Guede, diketahui kemampuan menelaah teks ulasan puisi dapat dikatakan meningkat, dengan antusias siswa dalam merespon pembelajaran teks ulasan pada puisi dengan memahami struktur teks ulasan yang diberikan berdasarkan langkah-langkah strategi Anticipation Guede, seperti diberikan panduan dalam mengerjakan dan memahami teks ulasan, kemudian sejumlah siswa mulai memberikan pertanyaan 
berupa materi yang kurang mereka pahami dalam menelaah teks ulasan puisi, setelah segala pertanyaan terselesesaikan siswa mulai dibentuk berdasarkan kelompok yang sudah di persiapkan, dan mereka mulai mengerjakan soal yang diberikan, dari tesnilai tertinggitertinggi90 danskor terendah44 dan dapat diketahui bahwa siswa yang mendapatkan nilai diatas 70 sebanyak 40 siswa (56\%).

\section{Pengaruh} Anticipation Terhadap kemampuan Menelaah Teks Ulasan Puisi

Berdasarkan pemaparan di atas dapat diketahui perbandingan tes awal dan tes akhir pada tes awal siswa yang dikatakan baik berjumlah $6 \%$ dan hasil rata-rata tes tes akhir sebesar $28 \%$. Maka jelas bahwa Penerapan Strategi Anticipation Guede sangat berpengaruh terhadap kemampuan menelaah teks ulasan puisi, karena dapat menambah wawasan siswa dan keaktivan siswa dalam proses pembelajaran. Hal tersebut menunjukan bahwa pembelajaran menelaah teks ulasan dengan menggunakan strategi Anticipation Guide lebih efektif dari pada pembelajaran menelaah teks ulasan tanpa menggunakan strategi Anticipation Guide.

Hasil penelitian ini mendukung penelitian dari Viera Budyariesqa (2013) berjudul "keefektifan penggunaan strategi panduan strategi dalam Pembelajaran Menelaah drama Bagi Siswa Kelas VIII SMP Negeri di Kecamatan Imogiri, Bantul".Hasil penelitian Budyariesqa (2013: 73) dapat disimpulkan bahwa penggunaan strategi Panduan Antisipasi dapat meningkatkan kemampuan menelaah sebuah drama. Hal ini dapat dilihat dari analisis statistik dengan teknik uji-t antara skor tes awal dengan tes akhir. Hasil uji-t dari skor tes awal dan tes akhir dihasilkan thitung = $6,807, \mathrm{db}=61$, dan $\mathrm{p}=0,000$. Nilai p lebih kecil dari taraf signifikansi $5 \%(0,000<0,05)$. Terdapat perbedaan yang signifikan pada kenaikan skor rata-rata tes awal ke tes akhir antara kelompok kontrol dan kelompok eksperimen dengan skor rata-rata kelompok kontrol lebih 
tinggi $(4,281)$ daripada kelompok kontrol $(0,355)$. Perbedaan kenaikan skor rata- rata tersebut menunjukan bahwa pembelajaran menelaah sebuah drama dengan menggunakan strategi Panduan Antisipasi strategi dari pada pembelajaran menelaah sebuah drama yang tidak menggunakan strategi Panduan Antisipasi.

\section{SIMPULAN DAN SARAN}

Dari hasil penelitian yang telah dilakukan, dapat disimpulkan sebagai berikut 1) Kemampuan siswa kelas VIII SMP Negeri 1 Aek Kuasan Tahun Pembelajaran 2018/2019 dalam menelaah teks ulasan puisi tanpa menggunakan strategi Anticipation Guede dapat dilihat dari rata-rata tes awalsiswa yaitu 41 dengan kategori cukup baik. Hal ini dikarenakan pada beberapa aspek penilaian siswa masih mengalami kekurangan. 2) Kemampuan siswa kelas VIII SMP Negeri 1 Aek Kuasan Tahun Pembelajaran 2018/2019 dalam menelaah teks ulasan puisi setelah diberi perlakuan dengan strategi Anticipation Guede dapat dilihat dari rata-rata tes akhirsiswa yaitu 69 dengan kategori baik. Dengan adanya perlakuan dari model dan media ini siswa lebih dirangsang untuk aktif dalam pembelajaran karena dengan mstrategi ini siswa dapat lebih nyata melihat objek yang akan mereka kaji dalam menelaah teks ulasan puisi. 3) Berdasarkan to yang diperoleh dari $t_{\text {tabel }}$ yaitu 5,97> 2,06, maka hipotesis alternatif (Ha) diterima. Hal ini membuktikan bahwa strategi Anticipation Guede bepengaruh terhadap kemampuan menelaah teks ulasan pada siswa kelas VIII SMP Negeri 1 Aek Kuasan.

Berdasarkan simpulan di atas, tindak lanjut penelitian ini perlu diungkapkan beberapa saran kepada peneliti dan guru bahasa Indonesia seperti yang tertulis berikut ini. Hasil penelitian ini menunjukan bahwa strategi Anticipation Guede berpengaruh positif kepada kemampuan menelaah teks ulasan. Oleh karena itu, strategi Anticipation Guede disarankan digunakan oleh guru bahasa Indonesia untuk menjadikan tingkat pemahaman keterampilan dalam menelaah teks 
ulasan, Untuk menggunakan strategi Anticipation Guede diperlukan pemahaman guru bahasa Indonesia baik dari segi persiapan, pelaksanaan, sampai penutup agar hal yang diharapkan yakni pembelajaran menelaah teks ulasan dapat lebih baik. Disarankan agar peneliti selanjutnya dapat menelaah strategi yang lain diluar Strategi Anticipation Guede dan dengan teks yang lain diluar teks ulasan.

\section{DAFTAR PUSTAKA}

Abidin, Yunus (2014). Desain Sistem Pembelajaran Dalam Konteks Kurikulum 2013. Bandung: Refika Aditama.

Arikunto (2006). Metode Penelitian.

Jakarta: Prenada Media

Grup.

Corrigan, Timothy. 2012. A Short Guide to Writing about Film. New York: Longman

Herman. J. Waluyo. 1987. Teori dan Apresiasi Puisi. Jakarta: Gramedia Pustaka Utama.
Irwansyah, 2009.

Seandainya Saya

Kritikus Film:

Pengantar Menulis

Kritik Film.

Yogyakarta: Homerian

Pustaka.

Kosasih (2012). Apresiasi Sastra

Indonesia. Jakarta: PT.

Perca.

Kozen, dkk (2006). Strategi

Pembelajaran. Malang: Bina Aksara.

Latsia, K. P. (2016). Kefektifan Pembelajaran Menyunting Teks Ulasan Film dengan Model Pembelajaran Think Pair Share dan Model Pembelajaran Snowball Throwing Pada Siswa Kelas XI SMA . Jurnal Nasional, 42-48. 